\title{
TRACE METAL CONCENTRATION AND HUMAN HEALTH RISK ASSESSMENT IN DISTILLED ALCOHOLIC BEVERAGES IN ROMANIA
}

\author{
FLORIN DUMITRU BORA ${ }^{\mathrm{a}^{*}}$, ANAMARIA CĂLUGĂR ${ }^{\mathrm{b}}$, \\ CLAUDIU IOAN BUNEA ${ }^{\mathrm{b}}$, VALENTIN PETRESCU MAG ${ }^{\mathrm{c}}$, \\ CLAUDIA CIMPOIU ${ }^{d}$, VASILE RĂZVAN FILIMON ${ }^{\mathrm{e}}$
}

\begin{abstract}
The concentration of 12 metals ( $\mathrm{Mg}, \mathrm{Ca}, \mathrm{K}, \mathrm{M}, \mathrm{Fe}, \mathrm{Co}, \mathrm{Ni}, \mathrm{Cr}$, $\mathrm{Cu}, \mathrm{Pb}, \mathrm{Cd}$, and $\mathrm{Zn}$ ) in 14 classes of alcoholic beverages were determined by ICP-MS after $\mathrm{HNO}_{3} / \mathrm{H}_{2} \mathrm{O}_{2}$ digestion. The mean concentration of metals $(\mu \mathrm{g} / \mathrm{mL})$ in these alcoholic beverages varied in the ranges $0.26-15.43,0.94-$ 234.43, 0.56-278.02, 0.02-2.69, 0.18-2.64, 0.03-0.13, 0.03-0.13, 0.02-0.29, 0.04-2.51, 0.03-0.30, 0.02-0.04, and 0.13-0.88 for $\mathrm{Mg}, \mathrm{Ca}, \mathrm{K}, \mathrm{Mn}, \mathrm{Fe}, \mathrm{Co}, \mathrm{Ni}$, $\mathrm{Cr}, \mathrm{Cu}, \mathrm{Pb}, \mathrm{Cd}$, and $\mathrm{Zn}$ respectively. The concentration of metals found in these particular alcoholic beverages was below the International Statutory Limits for metals in alcoholic beverages. The estimated daily intake of the metals based on a per capita consumption of $14.4 \mathrm{~L}$ per annum pure alcohol was lower than the tolerable daily intake of each metal. The individual and combined target hazard quotients of the metals were $<1$, indicating no longterm health concerns from the consumption of these alcoholic beverages based on their metal content alone.
\end{abstract}

Keywords: alcoholic beverages, daily intake, target hazard quotients, Romania.

a Research Station for Viticulture and Enology Targu Bujor, 65 G-ral Eremia Grigorescu, RO805200, Galați Country Romania

b University of Agricultural Sciences and Veterinary Medicine, Department of Horticulture and Landscaping, 3-5 Mănăştur Street, RO-400372 Cluj-Napoca, Romania

c University of Agricultural Sciences and Veterinary Medicine, Department of Agriculture, 3-5 Mănăştur Street, RO-400372 Cluj-Napoca, Romania

d Babeş-Bolyai University, Faculty of Chemistry and Chemical Engineering, 11 Arany Janos str., RO-400028, Cluj-Napoca, Romania

e Research Station for Viticulture and Enology lași, 48 Aleea Mihail Sadoveanu, RO-700489, lași Country Romania;

*Corresponding author: boraflorindumitru@gmail.com 


\section{INTRODUCTION}

The concentration of metals in many alcoholic beverages can be a significant parameter affecting their consumption and conservation. This derives from the negative and positive effects caused directly or indirectly by the presence of metals. Negative effects include beverage spoilage and hazing, as well as sensorial and health consequences [1]. Positive effects include the removal of bad odors and tasters [2], participation in fermentative processes [3], provision of pathways for dietary intake of some essential mineral [4], and usefulness for authentication purpose [5].

Metals find their way into alcoholic beverages at different stages and through various sources including raw materials, brewing, process type and equipment, bottling, aging/storage, and adulteration.

Several metal ions can be taken up from the surrounding soil by plants from which an alcoholic beverage is prepared. For instance, type of soil (i.e., it's geogenic), it's agrochemical treatments (e.g., the use of pesticides and fungicides), and the surrounding environmental pollution implies the mineral content of many beverages [6]. In this way, wines from vineyards in coastal areas are richer in $\mathrm{Na}$ [7]. Fungicides, pesticides, and fertilizers containing $\mathrm{Cd}$, $\mathrm{Cu}, \mathrm{Mn}, \mathrm{Zn}$ and $\mathrm{Pb}$, compounds can derive in increased contents of these metals in the alcoholic beverage [7]. Most of the $\mathrm{Mg}$ found in beer comes mainly from raw materials [1]. Cu in beer comes mainly from raw materials [4]; on the contrary, only a small percentage of the final Cu content in whiskey comes from the barely from which the spirit is distilled [8].

Hops, acids, silica gel, bases, flavoring agents, dilution water, additives, and stabilizers are potential sources of metal ions in the brewing process [4]. For example, the main source of $\mathrm{Cu}$ in wine is the $\mathrm{CuSO}_{2}$ added to remove sulfidic odors [2]. The acidity of the liquor to be distilled may be important in this regard (e.g., in whiskeys), since mare acidic beverage tend to contain more $\mathrm{Cu}$ [8]. The addition of fining and clarifying substances (e.g., flocculants) to reduce turbidity can bring about an increase in $\mathrm{Al}, \mathrm{Ca}, \mathrm{Na}$ in wine [7].

Major differences in metal content (e.g., Ni) have been found among alcoholic beverages depending on their processing. In this way, certain fermented beverages (e.g., beer and wine) contain several times more $\mathrm{Ni}$ than distilled beverages (e.g., brandy, vodka, and whiskey) [9].

Process equipment is frequently a key source of metal ions in the final products. Several examples follow: (1) the concentration of $\mathrm{Cu}$ comes from process equipment in vodka is twice as much that coming from raw materials [10]; in whiskey the main source of $\mathrm{Cu}$ is the copper still used for distillation process [8]; corrosion of tequila distillation equipment (made also from $\mathrm{Cu}$ ), 
provokes the presence of this in the final product [11]; storage of vodka in metal containers (e.g., Cu alloys or low-quality steel) results in their corrosion with the concomitant introduction of metals into the liquors [1], this is also the case with acidic wine vinegar [12]; the $\mathrm{Cu}, \mathrm{Fe}$, and $\mathrm{Zn}$ contained in homeproduced alcoholic drinks can be essentially unrelated to the material fermented as it primarily depends on the several materials [13]; degree of still and the temperature in the distillate affect the $\mathrm{Cu}$ content in whiskey [1]; extremely high concentration of $\mathrm{Fe}, \mathrm{Zn}$, and $\mathrm{Cu}$ in home-produced beers and spirits can be largely traced to use of galvanized metal fermentation drums, when these replace old clay and wooden vessels [14]; the Fe content from musts and pulps increases due to the Fe concrete tanks used for the storage of raw materials [1]; contact of wine with process equipment, barrels, casks, and pipes is the usual source of $\mathrm{Al}, \mathrm{Cd}, \mathrm{Cu}, \mathrm{Cr}, \mathrm{Fe}$, and $\mathrm{Zn}$ [7]; $\mathrm{Pb}$ plumbing can add $\mathrm{Pb}$ to beverages [2].

Metal addition from process equipment (e.g., stills) can be prevented by the use of high-quality steel or glass, although some organoleptic properties may be altered by the absence of certain metal ions added during distillation (e.g., the lack of minute amounts of $\mathrm{Cu}$ in tequila affects negatively its flavor).

Bottling equipment may also introduce metals in beverages. The content of $\mathrm{Ca}, \mathrm{Mg}$ and $\mathrm{Na}$ brandies depends on the quality of water used for dilution after distillation [1]. The modification of certain imported alcoholic beverages "to bottle and sale by the addition of distilled or otherwise purified water to adjust the beverage to a required strength" is sometimes allowed. It is noteworthy that when metallic capsules seal alcoholic beverage bottles, some $\mathrm{Pb}$ may be carried over [15].

Possible effects caused by metals during these stages are multiple. Fe (III) and Mn (II) affect the stability of old wines and modify their sensorial quality after bottling since they are believed to activate molecular oxygen by forming reactive oxygen species (e.g., hydroxyl radicals) this is possible due to their electronic configurations involving unpaired electrons that may interact quantum mechanically with the dioxygen triplet [7]. Likewise, Fe catalyzes the oxidation of polyphenolic substances and $\mathrm{Mn}$ facilitates acetaldehyde formation, the products of these reactions yield undesirable precipitates. $\mathrm{Cu}$ and $\mathrm{Zn}$ can be introduced into beer by welded cans [4].

In the case of adulteration process, $\mathrm{Pb}$ and other metallic impurities can enter beverages during adulteration practices, e.g., adulterated vodka has been found to contain an excess of $\mathrm{Ca}$ and $\mathrm{Mn}$ ions [1]. The objective of the present study was to determine the concentration of 12 metals $(\mathrm{Mg}, \mathrm{Ca}$, $\mathrm{K}, \mathrm{Fe}, \mathrm{Co}, \mathrm{Ni}, \mathrm{Cr}, \mathrm{Cu}, \mathrm{Pb}, \mathrm{Cd}$, and $\mathrm{Zn}$ ) in some alcoholic beverages, with a view to providing information on the metal profiles and risks associated with the consumption of these products. 


\section{RESULTS AND DISCUSSION}

\section{Wine Mineral Content}

The mean concentration of $\mathrm{Mg}$ in the studied samples ranged from 0.26 to $15.43 \mu \mathrm{g} / \mathrm{mL}$ with an average of $3.84 \mu \mathrm{g} / \mathrm{mL}$. The highest concentration of Mg was observed in cream liquors $(15.43 \pm 1.57 \mu \mathrm{g} / \mathrm{mL})$. The cream liquors, aperitif, local brandy, and local cider samples showed significantly higher mean concentrations $(p \leq 0.005)$. The lowest mean level of $\mathrm{Mg}$ in the drinks samples was observed in rum $(0.26 \pm 0.04 \mu \mathrm{g} / \mathrm{mL})$. Iwegbue et al. [16] and Cameán et al. [17] reported $\mathrm{Mg}$ concentrations in the range of $0.26-25.45 \mu \mathrm{g} / \mathrm{mL}$ [16] and $0.24-11.20 \mu \mathrm{g} / \mathrm{mL}$ [17]. The levels of $\mathrm{Mg}$ recorded in the present study were lower than the levels reported in the wine literature $98.20 \mathrm{mg} / \mathrm{L}$ [18], 95-73 mg/L [19], $75.20 \mathrm{mg} / \mathrm{L}$ [20] however, the concentration of $\mathrm{Mg}$ in these samples was comparable to the levels found in spirits, liquor and whiskey [21].

The mean concentration of $\mathrm{Ca}$ in the alcoholic beverages varied from 0.94 to $234.43 \mu \mathrm{g} / \mathrm{mL}$ with an average of $23.77 \mu \mathrm{g} / \mathrm{mL}$. Again, the highest concentration of $\mathrm{Ca}$ was observed in cream liquors $(234.43 \pm 10.58 \mu \mathrm{g} / \mathrm{mL})$. Cameán et al. [17] reported Ca levels ranging from 'not detected' to 14.80 $\mu \mathrm{g} / \mathrm{mL}$, while Iwegbue et al. [16] reported Ca levels from $1.43 \mu \mathrm{g} / \mathrm{mL}$ to 162.86 $\mu \mathrm{g} / \mathrm{mL}$. The high Ca concentration in the cream liquors could be due to enrichment of this type of drink with milk, which is known to contain substantial amounts of minerals [16]. The lowest mean level of $\mathrm{Ca}$ in the drinks samples was observed in dry gin $(0.94 \pm 0.05 \mu \mathrm{g} / \mathrm{mL})$. Lower level of Ca has been reported in the scientific literature in distilled products, 'not detected' to $14.80 \mathrm{mg} / \mathrm{L}$ (brandy) and from 6.00 to $11.00 \mathrm{mg} / \mathrm{L}$ (cognac) [22], $1.00 \mathrm{mg} / \mathrm{L}$ (gin) [23], $4.00 \mathrm{mg} / \mathrm{L}$ (rum) [23], $3.00 \mathrm{mg} / \mathrm{L}$ (rum) [22]. The concentration of Ca recorded in the present study was lower than the levels reported in the wine literature $83.50 \mathrm{mg} / \mathrm{L}$ [18], average values of $37.00 \mathrm{mg} / \mathrm{L}$ [19] and $65.90 \mathrm{mg} / \mathrm{L}$ [20]. In the coconut/orange liquor, showed significantly higher levels $(p \leq 0.005)$ of $\mathrm{Ca}$ than the other brands analysed in this group. Apart from a few brands of coconut/orange liquor, the concentration of $\mathrm{Ca}$ in other classes of drinks was comparable to the concentration of reported in Brazilian cachaça and spirits [24].

The mean concentration of $\mathrm{K}$ in the alcoholic drinks ranged between $0.02 \mu \mathrm{g} / \mathrm{mL}$ to $278.02 \mu \mathrm{g} / \mathrm{mL}$. The highest mean concentration of $\mathrm{K}$ was observed in cream liquors. The highest mean concentration of $\mathrm{K}$ varied significantly $(p \leq 0.005)$ within the same class, as well as in other classes. The lowest mean level of $\mathrm{Mg}$ in the drinks samples was observed in aromatic schnapps. Cameán et al. [17] reported a $\mathrm{K}$ concentration ranging from $0.11 \mu \mathrm{g} / \mathrm{mL}$ to $70.06 \mu \mathrm{g} / \mathrm{ml}$ and Iwegbue et al. [16] reported $\mathrm{K}$ levels from 
'not detected' to $322.58 \mu \mathrm{g} / \mathrm{mL}$. Except for cream liquors, the $\mathrm{K}$ concentration in these alcoholic drinks was similar to the levels of $\mathrm{K}$ reported in Brazilian sugar cane spirit [24]. The concentration of $\mathrm{K}$ recorded was lower than the levels reported in the wine literature from $491.12 \mathrm{mg} / \mathrm{L}$ to $633.74 \mathrm{mg} / \mathrm{L}$ for red wines and from $148.66 \mathrm{mg} / \mathrm{L}$ to $327.64 \mathrm{mg} / \mathrm{L}$ for white wines [25] and 819.61 $\mathrm{mg} / \mathrm{L}$ average value [26].

It was observed that the cream liquors contained a higher concentration of $\mathrm{Mg}, \mathrm{Ca}$ and $\mathrm{K}$ compared with the other classes of alcoholic beverages. This suggests that persons who drink cream liquors in preference to sprits and other types of alcoholic drinks studied in this research would be likely to be exposed to more metals.

The highest mean level of $\mathrm{Mn}$ was observed in cognac $(0.39 \mu \mathrm{g} / \mathrm{mL})$ and the lowest in aromatic schnapps $(0.02 \mu \mathrm{g} / \mathrm{mL})$. The maximum permissible limit of $\mathrm{Mn}$ in drinking water is $0.40 \mu \mathrm{g} / \mathrm{ml}$ lwegbue et al. [16]. The concentrations of $\mathrm{Mn}$ in the alcoholic beverages were lower than the permissible level in drinking water. Iwegbue et al. [16] reported Mn levels from 'not detected' to $0.33 \mu \mathrm{g} / \mathrm{mL}$. Lower levels of $\mathrm{Mn}$ were observed in this study in comparison with the levels reported in wines $0.83 \mathrm{mg} / \mathrm{L}$ [25], 1.89 $\mathrm{mg} / \mathrm{L}$ [18] and $2.04 \mathrm{mg} / \mathrm{L}$ [26], but were comparable to the levels reported from Brazilian cachaça and other international spirits [16].

The $\mathrm{Fe}$ concentration in the alcoholic beverages varied from 0.18 $\mu \mathrm{g} / \mathrm{mL}$ to $2.64 \mu \mathrm{g} / \mathrm{mL}$ with an average of $1.03 \mu \mathrm{g} / \mathrm{mL}$. The highest concentration of $\mathrm{Mn}$ was observed in spirit, while the lowest mean level was observed in aromatic schnapps. The guide provides a concentration of $\mathrm{Fe}$ in drinking water of $0.30 \mu \mathrm{g} / \mathrm{mL}$ [16]. The concentrations of Fe were higher than the permissible level in drinking water. Cameán et al. [17] reported Fe levels varying from 'not detected' to $2.03 \mu \mathrm{g} / \mathrm{mL}$ in Spanish brandy and Iwegbue et al. [16] reported Fe levels varying from $0.28 \mu \mathrm{g} / \mathrm{mL}$ to $1.48 \mu \mathrm{g} / \mathrm{mL}$. The concentration of $\mathrm{Fe}$ found in the alcoholic drinks was comparable to the levels in $\mathrm{Fe}$ reported in the literature for other alcoholic beverages in beer and wine $0-25 \mathrm{mg} / \mathrm{L}[26 ; 15]$, in brandy 'not detected' to $2.30 \mathrm{mg} / \mathrm{L}[28 ; 15$; 22], cognac $0.1 \mathrm{mg} / \mathrm{L}$ [28], gin 'not detected' [28] rum $1.00 \mathrm{mg} / \mathrm{L}$ [28], vodka 'not detected' [28], whiskey 'not detected' [28], $1.48 \mathrm{mg} / \mathrm{L}$ spirits [16], 0.29 $\mathrm{mg} / \mathrm{L}$ brandy [16], $0.29 \mathrm{mg} / \mathrm{L}$ aromatic schnapps [16].

Co concentration in the beverages varied from $0.03 \mu \mathrm{g} / \mathrm{mL}$ to 0.16 $\mu \mathrm{g} / \mathrm{mL}$, with whiskey and aromatic schnapps having the maximum and minimum mean levels, respectively. The highest mean concentration of Co varied significantly $(p \leq 0.005)$ within the same class, as well as in other classes. Xuebo et al. [29] reported a Co concentration ranging from 0.37 $\mathrm{mg} / \mathrm{L}$ to $0.89 \mathrm{mg} / \mathrm{L}$ in baijiu (Chinese liquors) and lwegbue et al. [16] reported Co levels varying from 'not detected' to $0.12 \mu \mathrm{g} / \mathrm{mL}$. Lower levels of Co were 
observed in this study in comparison with the levels reported in wines from $2.60 \mathrm{mg} / \mathrm{L}$ to $7.63 \mathrm{mg} / \mathrm{L}$ [25].

The mean concentration of $\mathrm{Ni}$ in the drinks varied between $0.02 \mu \mathrm{g} / \mathrm{mL}$ and $0.13 \mu \mathrm{g} / \mathrm{mL}$. The highest mean concentration of Ni was observed in brandy and the lowest mean concentration was observed in aromatic schnapps. The maximum permissible limit of $\mathrm{Ni}$ in drinking water is $0.02 \mu \mathrm{g} / \mathrm{mL}$ lwegbue et al. [16]. The mean concentration of $\mathrm{Ni}$ in most classes of these alcoholic beverages exceeded the maximum prescribed limit for $\mathrm{Ni}$ in drinking water. Iwegbue et al. [16], Xuebo et al. [29] and Ibanez et al. [1], also reported $\mathrm{Ni}$ mean concentration in alcoholic beverages which exceeded the maximum prescribed limit for $\mathrm{Ni}$ in drinking water. $\mathrm{Ni}$ concentration reported in this research were higher than the $0.0812-0.115 \mu \mathrm{g} / \mathrm{mL}$ reported in Brazilian cachaça and were comparable to levels reported for other alcoholic beverages $0.13 \mu \mathrm{g} / \mathrm{mL}$ in aromatic schnapps and 0.05 cognac 16]. Lower levels of Ni were observed in alcoholic beverages (this study) in comparison with the levels reported in wines from $0.073 \mathrm{mg} / \mathrm{L}$ to $19.40 \mathrm{mg} / \mathrm{L}$ [1].

The highest mean concentration of $\mathrm{Cr}$ was observed in cream liquor $(0.29 \mu \mathrm{g} / \mathrm{mL})$ and the lowest mean concentration was observed in spirit $(0.02$ $\mu \mathrm{g} / \mathrm{mL})$. The highest mean concentration of $\mathrm{Cr}$ varied significantly $(p \leq 0.001)$ within the same class, as well as in other classes. Similar level of $\mathrm{Cr}$ has been reported in the literature [16] for alcoholic beverages, namely 0.28 $\mu \mathrm{g} / \mathrm{mL}$ in cream liquor, $0.03 \mu \mathrm{g} / \mathrm{mL}$ in cognac and $0.05 \mu \mathrm{g} / \mathrm{mL}$ in punch, while level of $\mathrm{Cr}$ concentration in wine was higher $(872.42 \mu \mathrm{g} / \mathrm{L})$ than in the studied alcoholic beverages.

The mean concentration of $\mathrm{Cu}$ in the samples ranged from 0.04 $\mu \mathrm{g} / \mathrm{mL}$ to $2.51 \mu \mathrm{g} / \mathrm{mL}$, with an average of $0.43 \mu \mathrm{g} / \mathrm{mL}$. The highest mean concentration of $\mathrm{Cu}$ was observed in cream liquor, while the lowest mean level was observed in the punch. The permissible limit of $\mathrm{Cu}$ in alcoholic beverages is set at $5.0 \mu \mathrm{g} / \mathrm{mL}$ [16]. The mean concentration of $\mathrm{Cu}$ in these alcoholic beverages was below the permissible limit. $\mathrm{Cu}$ concentration in the range of 1.64 to $4.40 \mu \mathrm{g} / \mathrm{mL}$ [16] has been reported for Brazilian cachaça and other international spirits [1].

Similar, in Spain the Cu concentration was in the range of $0.10 \mu \mathrm{g} / \mathrm{mL}$ to $8.01 \mu \mathrm{g} / \mathrm{mL}$ for brandy, gin, rum, liquor, and whiskey, in Denmark, Cu leaves was in the rage of 'not detected' to $0.12 \mu \mathrm{g} / \mathrm{mL}$, were reported in for gin, rum, brandy and liquor [16]. The concentration of $\mathrm{Cu}$ found in the alcoholic drinks was comparable to the levels in Cu reported in the literature for other alcoholic beverages in spirits $0.40 \mathrm{mg} / \mathrm{L}$ [15], sherry brandy 0.22 to $5.31 \mathrm{mg} / \mathrm{L}$ [17], and in wine, fruit wine, cocktails from 'not detected' to $7.62 \mathrm{mg} / \mathrm{L}$ [1]. 


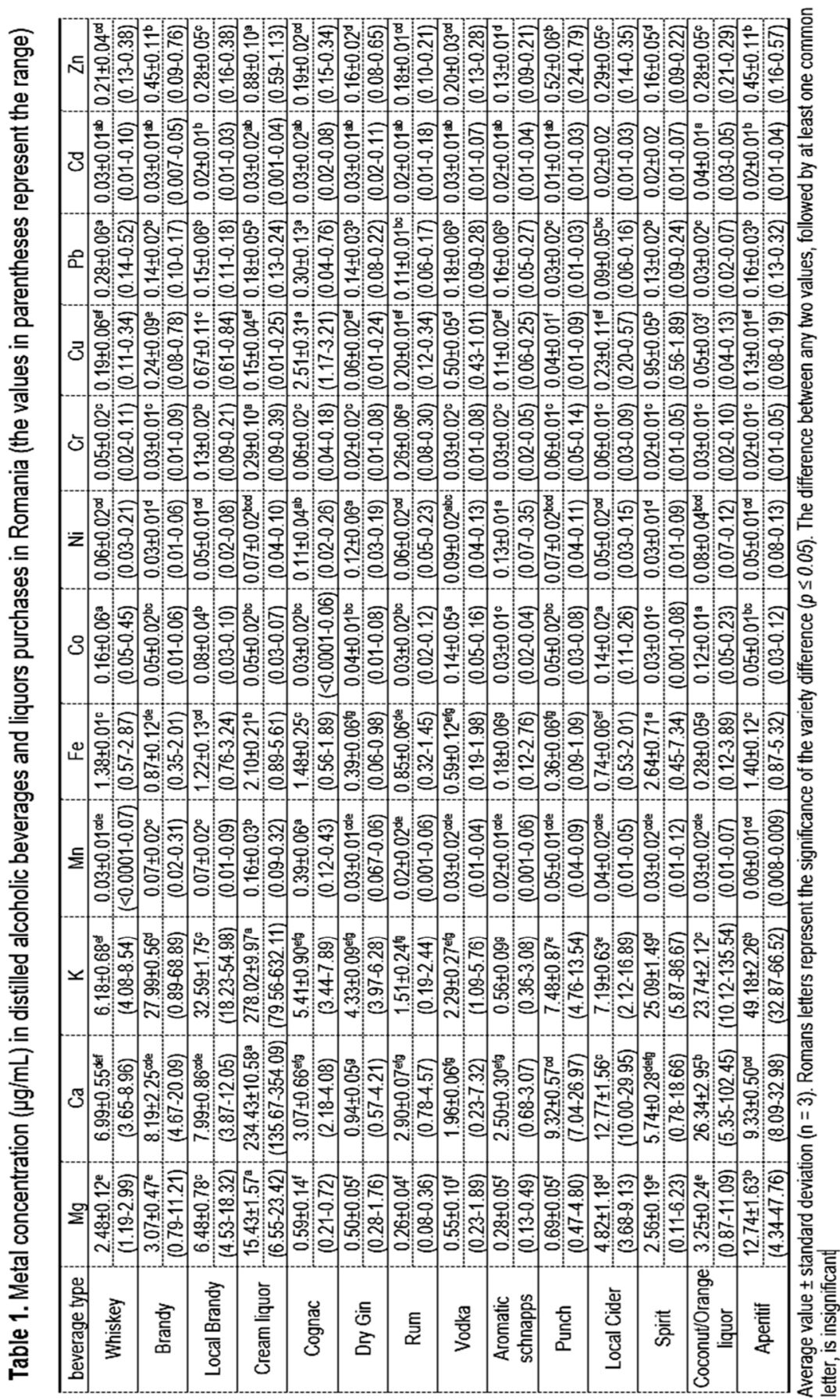


The mean levels of $\mathrm{Pb}$ in alcoholic beverages ranged from 0.03 $\mu \mathrm{g} / \mathrm{mL}$ to $0.30 \mu \mathrm{g} / \mathrm{mL}$. The highest mean concentration was observed in cognac, while the lowest mean value is in a punch, a home-made drink made from alcohol and fruits or fruit juice. These values are in accordance with Iwegbue et al. [16]. The acceptable limits for $\mathrm{Pb}$ in alcoholic beverages in some European countries are in the range of $0.20 \mu \mathrm{g} / \mathrm{mL}$ to $0.50 \mu \mathrm{g} / \mathrm{mL}$. The mean concentration of $\mathrm{Pb}$ in these alcoholic beverages are below the permissible limit. The concentration of $\mathrm{Pb}$ found in the alcoholic drinks was comparable to the levels of $\mathrm{Pb}$ reported in the literature for other alcoholic beverages, which are from 'not detected' to $0.46 \mathrm{mg} / \mathrm{L}$ in beer [14], 'not detected' to $0.22 \mathrm{mg} / \mathrm{L}$ in spirits [15], 0.008 to $0.420 \mathrm{mg} / \mathrm{L}$ in cognac [22], 'not detected' to $0.035 \mathrm{mg} / \mathrm{L}$ in gin [15], and 'not detected' to $1.125 \mathrm{mg} / \mathrm{L}$ in wine, fruit wine, cocktails [1].

The mean concentration of $\mathrm{Cd}$ in these alcoholic beverages were similar except for local brandy, which had a mean level that was twice the level found in the other classes. The mean concentration of $\mathrm{Cd}$ ranged from $0.02 \mu \mathrm{g} / \mathrm{mL}$ to $0.04 \mu \mathrm{g} / \mathrm{mL}$. The guideline value for $\mathrm{Cd}$ in drinking water is $0.05 \mu \mathrm{g} / \mathrm{mL}$ according to Iwegbue et al. [16]. The mean concentration of $\mathrm{Cd}$ in these alcoholic beverages was below the upper boundary these limits. The results of these studies indicate that persons who consume local brandy, in preference to other alcoholic beverages, are likely to be exposed to more $\mathrm{Cd}$. Iwegbue et al. [16] came to the same conclusion in terms of coconut liquor consumption. The levels of Cd observed in these drinks were comparable to the levels of $\mathrm{Cd}$ reported for other alcoholic beverages in the scientific literature $<0.005 \mathrm{mg} / \mathrm{L}$ in berry liquors [1], sherry brandy from $5.31-0.30 \mathrm{mg} / \mathrm{L}$ [17] and from 'not detected' to $0.052 \mathrm{mg} / \mathrm{L}$ in wine, fruit wines, cocktails. Iwegbue et al. [16] reported Cd levels from 'not detected' to $0.04 \mu \mathrm{g} / \mathrm{mL}$ in alcoholic beverages.

The mean concentration of $\mathrm{Zn}$ ranged from $0.13 \mu \mathrm{g} / \mathrm{mL}$ to $0.88 \mu \mathrm{g} / \mathrm{mL}$ with $0.31 \mu \mathrm{g} / \mathrm{mL}$ average value. The highest mean level of $\mathrm{Zn}$ was observed in cream liquor, while the lowest mean level was observed in aromatic schnapps. The permissible limit for $\mathrm{Zn}$ in alcoholic beverages is $5 \mu \mathrm{g} / \mathrm{mL}$ according to Iwegbue et al. [16]. The mean concentration of $\mathrm{Zn}$ in these alcoholic beverages was below the upper boundary these limits. Zn level concentration of $44 \mu \mathrm{g} / \mathrm{mL}$ to $69 \mu \mathrm{g} / \mathrm{mL}$ in rum and from $0124 \mu \mathrm{g} / \mathrm{mL}$ to 0.151 $\mu \mathrm{g} / \mathrm{mL}$ in cachaça and international spirits from Brazil have been reported by Iwegbue et al. [16]. The concentration of $\mathrm{Zn}$ found in the alcoholic drinks was comparable to the levels in $\mathrm{Zn}$ reported in the literature for other alcoholic beverages, like beer $0.1 \mathrm{mg} / \mathrm{L}$ - $68 \mathrm{mg} / \mathrm{L}$ [14; 15], brandy $3.0 \mathrm{mg} / \mathrm{L}$ [15; 22; 
28], cognac $0.016 \mathrm{mg} / \mathrm{L}$ to $3.00 \mathrm{mg} / \mathrm{L}$ [28], gin $0.5 \mathrm{mg} / \mathrm{L}$ [28], rum $3.00 \mathrm{mg} / \mathrm{L}$ [28], vodka 'not detected' [28], whiskey $0.50 \mathrm{mg} / \mathrm{L}$ [28], spirits $3.0 \mathrm{mg} / \mathrm{L}$ [16], brandy $3.00 \mathrm{mg} / \mathrm{L} \mathrm{[16]} \mathrm{and} 0.12 \mathrm{mg} / \mathrm{L}$ aromatic schnapps [16].

\section{Dietary intake of metals and target hazard quotients (THQs)}

The estimated daily intake of metals based on a per capita consumption of $14.4 \mathrm{~L}$ per annum of pure alcohol is displayed in Table 2. The estimated THQs of the metals are displayed in Table 3. The intake values of $\mathrm{Mg}$ in this study were in the range of $0.14-8.60 \mu \mathrm{g} / \mathrm{kg}$ b.w. per day. Higher intakes of $\mathrm{Mg}$ are likely for consumers of whiskey, brandy, local brandy, cream liquor, local cider, spirit, coconut/orange liquors, and aperitif. The recommended dietary allowance (RDA) values for male and female healthy adults are $400-420 \mathrm{mg} /$ day and 310-320 mg/day, respectively [16]. Based on the results obtained, the dietary intake of $\mathrm{Ca}$ from the consumption of these drinks is in the range of $0.27-130.61 \mu \mathrm{g} / \mathrm{kg}$ b.w. per day. Higher intakes of $\mathrm{Ca}$ are likely for consumers of whiskey, brandy, local brandy, cream liquor, cognac, rum, vodka, aromatic schnapps, punch, local cider, spirit, coconut/orange liquors, and aperitif. The RDA value of $\mathrm{Ca}$ is set at $1000 \mathrm{mg}$ per day [16]. The dietary intake of $\mathrm{K}$ from the consumption of these alcoholic beverages ranged from $0.31-154.90 \mu \mathrm{g} / \mathrm{kg}$ b.w. per day. Persons who drink cream liquor in preference to other types of the drink have higher $\mathrm{K}$ intake. Iwegbue et al. [16] reported dietary intake of $\mathrm{Mg}$, Ca and $\mathrm{K}$ from consumption of distilled alcoholic beverages and liquors for international origin as 0.07 $4.24,0.23-27.14$ and $0.08-53.76 \mu \mathrm{g} / \mathrm{kg}$ b.w. per day based on $3.6 \mathrm{~L}$ per annum per capita consumption. The estimated intake of $\mathrm{Mn}$ and $\mathrm{Fe}$ were 0.01-0.09 and 0.10-117.00 $\mu \mathrm{g} / \mathrm{kg}$ b.w. per day, respectively. Higher intakes of $\mathrm{Mn}$ and $\mathrm{Fe}$ are likely for consumers of cream liquors and spirits. The recommended dietary allowances value for Fe and $\mathrm{Mn}$ are 2-5 and 10-18 mg per day, respectively, according to Iwegbue et al. [16].

The RDA value for Co is $100 \mu \mathrm{g}$ per day according to Iwegbue et al. [16]. The estimated dietary intake of Co from these types of alcoholic beverages was lower than the RDA for Co. The recommended dietary allowance value for $\mathrm{Ni}$ is in the range of $35-700 \mu \mathrm{g} / \mathrm{kg} \mathrm{b.w}$. per day. The estimated intake values for Ni varied from of $0.02-0.07 \mu \mathrm{g} / \mathrm{kg} \mathrm{b} . w$. per day. The recommended dietary allowances value for $\mathrm{Ni}$ is $5 \mu \mathrm{g} / \mathrm{kg}$ b.w. per day. 
The estimated dietary intake of $\mathrm{Cu}$ and $\mathrm{Cr}$ was $0.02-1.40$ and $0.01-0.16 \mu \mathrm{g} / \mathrm{kg}$ b.w. per day. The highest intake values of $\mathrm{Cr}$ and $\mathrm{Cu}$ was observed in cream liquor and cognac. The RDA values for $\mathrm{Cu}$ and $\mathrm{Cr}$ per person are $900-30 \mathrm{mg}$ per day (15-500 $\mu \mathrm{g} / \mathrm{kg}$ b.w. per day) and $130 \mu \mathrm{g} / \mathrm{kg} \mathrm{b.w.} \mathrm{per} \mathrm{day,} \mathrm{respectively}$ according to Iwegbue et al. [16].

The estimated daily intake of $\mathrm{Pb}$ from consumption of any type of these alcoholic beverages ranged between $0.02-0.16 \mu \mathrm{g} / \mathrm{kg}$ b.w. per day. The Joint Food and Agriculture Organization/World Health Organization Expert Committee on Food Additives (JECFA) established a limit for $\mathrm{Pb}$ (3.6 $\mu \mathrm{g} / \mathrm{kg}$ b.w. per day). The dietary intake of Cd from the consumption of these classes of alcoholic beverages is in the range of $0.01-0.02 \mu \mathrm{g} / \mathrm{kg} \mathrm{b} . \mathrm{w}$. per day. The tolerable dietary intake of $C d$ is set at $1 \mu \mathrm{g} / \mathrm{kg} \mathrm{b.w.} \mathrm{per} \mathrm{day} \mathrm{according}$ to Iwegbue et al. [16]. The intakes of $\mathrm{Zn}$ from the consumption of these alcoholic drinks were $0.07-0.49 \mu \mathrm{g} / \mathrm{kg}$ b.w. per day. Higher intakes of $\mathrm{Zn}$ are likely for consumers of cream liquor, punch, and aperitif. The JECFA provisional maximal tolerable daily intake of $Z \mathrm{n}$ is $1000 \mu \mathrm{g} / \mathrm{kg}$ b.w. per day [16].

Table 2 presents the results of the estimated THQ from the consumption of these alcoholic drinks. The interpretation of the THQ values is binary: THQ is either $\geq 1$ or $<1$, where $T H Q>1$ indicates a health concern [30; 31; 32; 33; 16]. It must be noted that THQ is not a measured risk [30; 16; 34], but rather indicates a level of concern, and while THQ values are additive, they are not multiplicative, for example, the level of concern at $\mathrm{THQ}=20$ is larger than, but not 10 -hold, that at $T H Q=2$ according to Iwegbue et al. [16]. The estimated THQ values for the individual and combined metals from consumption of these drinks were $<1$ (Table 3 ). The THQ values reveal no significant concern to health for people with a $14.4 \mathrm{~L}$ per annum per capita consumption rate.

Risk assessment for a specific contaminant intake comprehensive consideration of all intake mechanisms, and alcoholic beverages consumption was just one such path, the amount of wine consumption was, therefore, more important for health risk assessment of wine in the daily diet of drinkers. 
TRACE METAL CONCENTRATION AND HUMAN HEALTH RISK ASSESSMENT IN DISTILLED ...
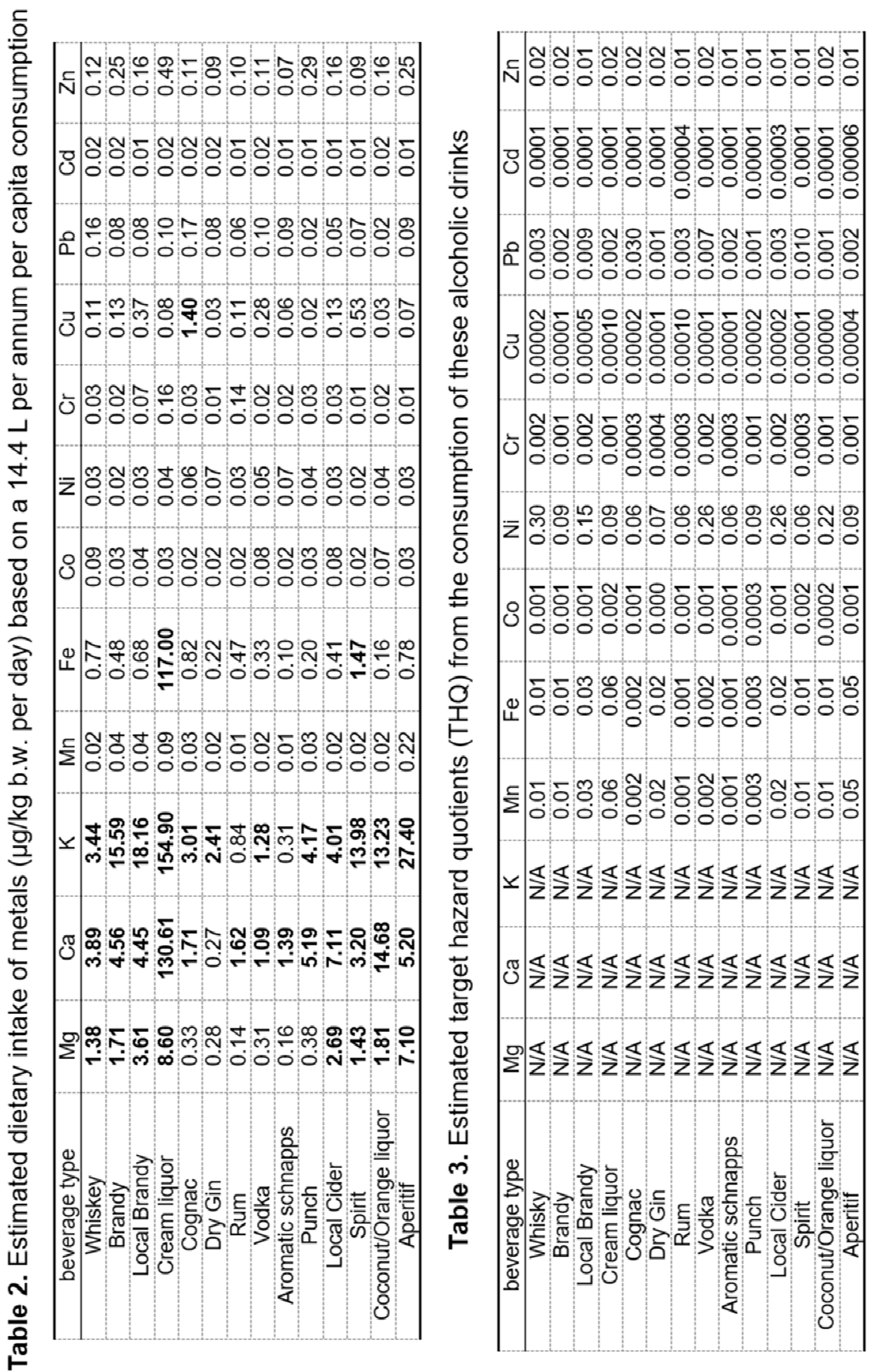


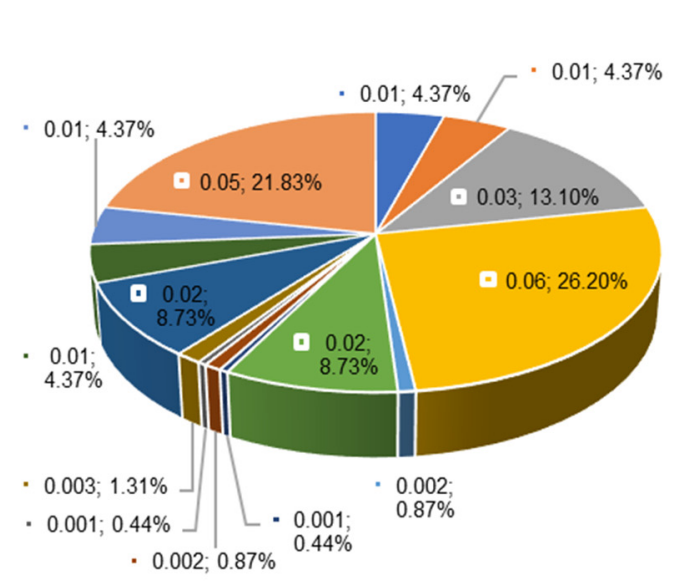

$$
\begin{aligned}
& \text { " Whisky } \\
& \text { " Brandy } \\
& \text { " Local Brandy } \\
& \text { = Cream liquor } \\
& \text { " Cognac } \\
& \text { " Dry Gin } \\
& \text { - Rum } \\
& \text { - Vodka } \\
& \text { " Aromatic schnapps } \\
& \text { " Punch } \\
& \text { - Local Cider } \\
& \text { - Spirit }
\end{aligned}
$$

Figure 1. The average proportion of the total THQ for all the alcoholic beverages

In this research the THQ also represented the contribution of alcoholic beverages to contaminants in the acceptable range for daily diet, the average THQ of cream liquor was $26.20 \%$ (Figure 1) and Co $89.15 \%$ (Figure 2) which meant that the contribution of cream liquors consumption to the tolerable daily intake of Co was $89.15 \%$.

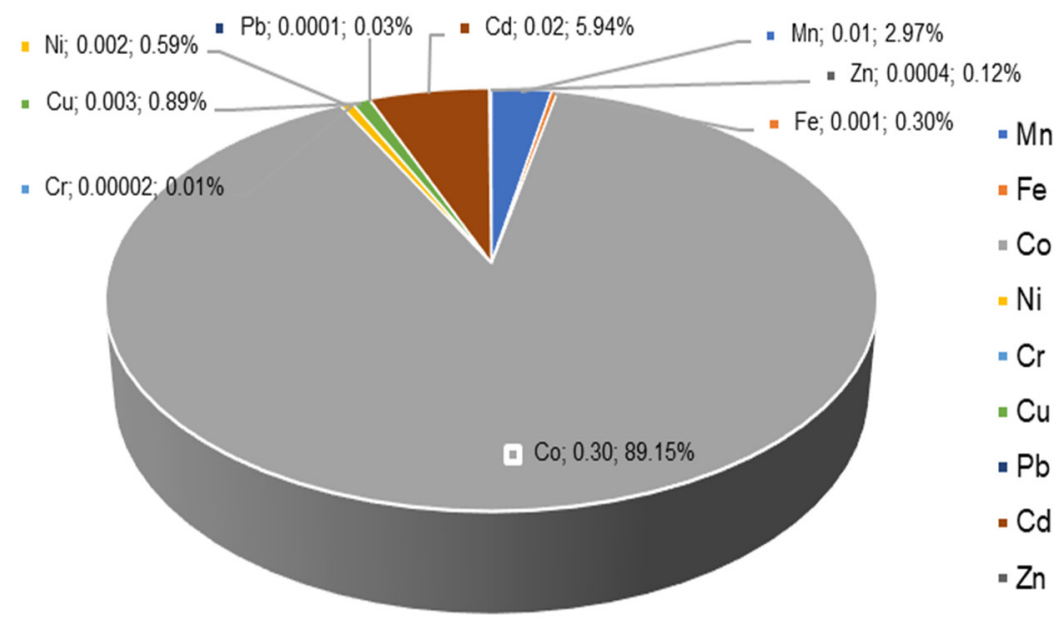

Figure 2. The average proportion of the total THQ for all the metals 


\section{CONCLUSIONS}

Relatively low levels of both essential and potential hazardous metal ions were found in these types of alcoholic beverages. Based on a $14.4 \mathrm{~L}$ per capita consumption of pure alcohol, the local and international drinks instigated gave low dietary intakes of the essential and potentially toxic metals. It was observed that the cream liquors and cognac contained a higher concentration of $\mathrm{Mg}, \mathrm{Ca}, \mathrm{K}, \mathrm{Fe}$, and $\mathrm{Cu}$ compared with the other classes of alcoholic beverages. This suggests that persons who drink cream liquors in preference to spirits and other types of alcoholic drinks studied in this research would be likely to be exposed to more metals.

The THQ values may not present any detrimental health concerns for a lifetime based on the metal content alone. However, the hazardous and harmful use of alcohol is a major global contributing factor, such as liver cirrhosis, cancers, alcohol dependences, injuries, and others through the dangerous actions of intoxicated people.

\section{EXPERIMENTAL SECTION}

\section{Sampling}

Samples of different brands of alcoholic beverages with different batch numbers and manufacturing dates were collected from retail operations in Bucharest, Cluj, Maramureș, Constanța, Galați, Braila, Satu-Mare, Salaj, Vâlcea, Alba, Covasna, Hargita and Mureș. The choice of brands was carefully made to reflect popular brands consumed by different income classes and influenced by availability at the time of purchase. The categorization and other information on the bottles of the alcoholic drinks are displayed in Table 4. The samples were stored at $3-5^{\circ} \mathrm{C}$ until the analysis was made.

Table 4. Information on the samples studied

\begin{tabular}{|c|c|c|c|}
\hline Alcoholic beverage & $\begin{array}{c}\text { Percentage } \\
\text { (v/v) alcohol }\end{array}$ & Class & $\begin{array}{c}\text { Country of } \\
\text { origin }\end{array}$ \\
\hline Johnnie Walker & 40 & Whisky & UK \\
\hline Small Batch & 46.85 & Whisky & America \\
\hline Ardreg Ulgeadail & 46 & Whisky & Scotland \\
\hline Arran Lochranza & 43 & Whisky & Scotland \\
\hline Ballantine's & 40 & Whisky & Italy \\
\hline Balvenie & 40 & Whisky & Scotland \\
\hline Benriach & 40 & Whisky & Scotland \\
\hline
\end{tabular}




\begin{tabular}{|c|c|c|c|}
\hline Alcoholic beverage & $\begin{array}{c}\text { Percentage } \\
\text { (v/v) alcohol }\end{array}$ & Class & $\begin{array}{c}\text { Country of } \\
\text { origin }\end{array}$ \\
\hline Big Peat & 46 & Whisky & Scotland \\
\hline Blanton's & $51.5 \%$ & Whisky & America \\
\hline Braeval & 48.4 & Whisky & Scotland \\
\hline Baffalo Trace & $40 \%$ & Whisky & America \\
\hline Bulleit Bourbon & 45.6 & Whisky & America \\
\hline Dalmore & 40 & Whisky & Scotland \\
\hline Dramsylvania & 40 & Whisky & Scotland \\
\hline Afinată & 40 & Brandy & Romania \\
\hline Caisată & 40 & Brandy & Romania \\
\hline Căpșunată & 40 & Brandy & Romania \\
\hline Vișinată & 40 & Brandy & Romania \\
\hline Plums brandy & 40 & Brandy & Romania \\
\hline Pears brandy & 40 & Brandy & Romania \\
\hline Quince brandy & 40 & Brandy & Romania \\
\hline Apricots brandy & 40 & Brandy & Romania \\
\hline Nuts liqueur & 35 & Cream liquor & Romania \\
\hline Black blueberry & 31 & Cream liquor & Romania \\
\hline liqueur & & & Grermany \\
\hline Jägermeister & 35 & Cream liquor & Germaly \\
\hline Amaretto Disaronno & 28 & Cream liquor & Italy \\
\hline Aperol & 11 & Cream liquor & Italy \\
\hline Unicum & 40 & Cream liquor & Hungary \\
\hline De kuyper & 40 & Cream liquor & Netherlands \\
\hline Courvoisier Cognac & 40 & Cognac & France \\
\hline Hennessy & 40 & Cognac & France \\
\hline Martel & 40 & Cognac & France \\
\hline Remy Martin & 40 & Cognac & France \\
\hline Wembley London & 40 & Dry Gin & England \\
\hline Beefeater London & 40 & Dry Gin & England \\
\hline Gordons & 37.5 & Dry Gin & UK \\
\hline Finsbury & 40 & Dry Gin & UK \\
\hline London Hill & 43 & Dry Gin & UK \\
\hline Havana Club & 40 & Rum & Cuba \\
\hline Matusalem & 40 & Rum & Dominican \\
Republic \\
\hline Stroh 80 & 80 & Rum & Austria \\
\hline Bacardi & 40 & Rum & Cuba \\
\hline Captain Morgan & 35 & Rum & Jamaica \\
\hline Finsolut Vodka & 40 Vodia Vodka & 40 & Sweden \\
\hline Rasputin Vodka & 40 & Finland \\
\hline
\end{tabular}


TRACE METAL CONCENTRATION AND HUMAN HEALTH RISK ASSESSMENT IN DISTILLED ...

\begin{tabular}{|c|c|c|c|}
\hline Alcoholic beverage & $\begin{array}{c}\text { Percentage } \\
(\mathbf{v} / \mathbf{v}) \text { alcohol }\end{array}$ & Class & $\begin{array}{c}\text { Country of } \\
\text { origin }\end{array}$ \\
\hline Stolichnaya & 40 & Vodka & Russia \\
\hline Zubrowka & 40 & Vodka & Poland \\
\hline Wyborowa & 40 & Vodka & Poland \\
\hline Eagles & 42 & Aromatic schnapps & Nigeria \\
\hline Seamans & 40 & Aromatic schnapps & Nigeria \\
\hline Kp & 42 & Aromatic schnapps & Nigeria \\
\hline Crown & 40 & Aromatic schnapps & Nigeria \\
\hline Garvey & 30 & Punch & Spain \\
\hline Freihof Jagertee & 40 & Punch & Austria \\
\hline Stroh Jagertee & 40 & Punch & Austria \\
\hline Local cider & 4.5 & Cider & Romania \\
\hline Tequila Blanco & 38 & Spirit & Mexico \\
\hline Absolute Citron & 40 & Sprit & Sweden \\
\hline Gordons Spark & 5.5 & Sprit & Nigeria \\
\hline Malibu & 21 & Coconut liquor & UK \\
\hline Calypso & 28 & Coconut liquor & Nigeria \\
\hline Blue Curaçao & 33.8 & Coconut liquor & USA \\
\hline Sweet „n” sour mix & 32 & Coconut liquor & USA \\
\hline Cointreau & 40 & Orange liquor & France \\
\hline Campari & 20 & Aperitif & Italy \\
\hline Bacardi & 40 & Aperitif & Germany \\
\hline Vino din tavola & 10.5 & Aperitif & Italy \\
\hline Ricard & 45 & Aperitif & France \\
\hline & & &
\end{tabular}

\section{Reagents and solutions}

Twelve elements ( $\mathrm{Mg}, \mathrm{Ca}, \mathrm{K}, \mathrm{Mn}, \mathrm{Fe}, \mathrm{Co}, \mathrm{Ni}, \mathrm{Cr}, \mathrm{Cu}, \mathrm{Pb}, \mathrm{Cd}$, and $\mathrm{Zn}$ ) were determined in 14 classes of alcoholic beverages. The analysis was made using multielement analysis and ICP-MS technique, after appropriate dilution, using the external standard calibration method (Table 5). The calibration was performed using XXICertiPUR multielement standard and from an individual standard solution of $\mathrm{Cr}$ and $\mathrm{Hg}$. The working standards and the control sample were prepared daily from the intermediate standards that were prepared from the stock solution. The intermediate solutions stored in polyethylene bottles and glassware was cleaned by soaking in $10 \% \mathrm{v} / \mathrm{v} \mathrm{HNO}_{3}$ for 24 hours and

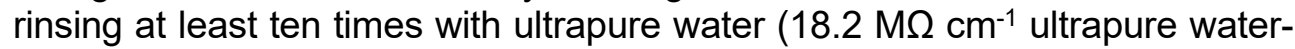
Types 1). The accuracy of the methods was evaluated by replicate analyses of fortified samples (10 $\mu \mathrm{L}-10 \mathrm{~mL}$ concentrations) and the obtained values ranged between 0.8-13.1 percent, depending on the element. The global recovery for each element was estimated and the obtained values were between $84.6-100.9 \%$ [35]. 
Table 5. Instrumental conditions for the determination of each element (ICP-MS technique)

\begin{tabular}{|c|c|c|c|c|}
\hline Element & Correlation coefficient & $\begin{array}{c}\mathrm{LoD}^{*} \\
(\mu \mathrm{g} / \mathrm{L})\end{array}$ & $\begin{array}{c}\mathrm{LoQ}^{* * *} \\
(\mu \mathrm{g} / \mathrm{L})\end{array}$ & $\begin{array}{c}\mathrm{BEC} \\
(\mu \mathrm{g} / \mathrm{L})\end{array}$ \\
\hline $\mathrm{Mg}$ & 0.9999 & 2.7320 & 9.0990 & 9.0990 \\
\hline $\mathrm{Ca}$ & 0.9999 & 5.6640 & 18.8640 & 20.8200 \\
\hline $\mathrm{K}$ & 0.9999 & 2.1860 & 7.2790 & 31.7281 \\
\hline $\mathrm{Mn}$ & 0.9999 & 0.0100 & 0.0340 & 0.0850 \\
\hline $\mathrm{Fe}$ & 0.9999 & 5.2100 & 17.3501 & 71.3990 \\
\hline $\mathrm{Co}$ & 0.9999 & 0.0365 & 0.1215 & 0.152 \\
\hline $\mathrm{Ni}$ & 0.9999 & 0.0591 & 0.1968 & 0.091 \\
\hline $\mathrm{Cr}$ & 0.9999 & 1.6630 & 5.5378 & 0.636 \\
\hline $\mathrm{Cu}$ & 0.9999 & 0.0402 & 0.1339 & 0.237 \\
\hline $\mathrm{Pb}$ & 0.9999 & 0.0003 & 0.0010 & 0.002 \\
\hline $\mathrm{Cd}$ & 0.9999 & 0.0202 & 0.0673 & 0.027 \\
\hline $\mathrm{Zn}$ & 0.9999 & 0.3780 & 1.2580 & 5.401 \\
\hline
\end{tabular}

*Detection limit; ${ }^{* *}$ Background equivalent concentration; ${ }^{* * *}$ Quantification limit.

For quality control purposes, blanks and triplicates samples $(n=3)$ were analysed during the procedure. The variation coefficient was under $5 \%$ and detection limits (ppb) were determined by the calibration curve method. Limit of detection (LoD) and Limit of quantification (LoQ) limits was calculated according to the next mathematical formulas: $\mathrm{LoD}=3 \mathrm{SD} / \mathrm{s}$ and $\mathrm{LoQ}=10$ $\mathrm{SD} / \mathrm{s}(\mathrm{SD}=$ estimation of the standard deviation of the regression line; $\mathrm{s}=$ slope of the calibration curve).

\section{Sample preparation for determination of metals using ICP-MS}

For the determination of elements from wine samples $0.5 \mathrm{~mL}$ wine were mixed with $7 \mathrm{~mL}$ of $\mathrm{HNO}_{3} 65 \%$ and $1 \mathrm{~mL}$ of $\mathrm{H}_{2} \mathrm{O}_{2}$ and were mineralized in a clean Teflon digestion vessel using a microwave system Milestone START D Microwave Digestion System. Mineralization was done in three steps: step I (time $10 \mathrm{~min}$., temperature $200^{\circ} \mathrm{C}$ ), step II (time $15 \mathrm{~min}$., temperature $200^{\circ} \mathrm{C}$ ) and step III (time $40 \mathrm{~min}$., ventilation - temperature $32^{\circ} \mathrm{C}$ ). After mineralization, samples were filtered through a $0.45 \mathrm{~mm}$ filter paper and the volume was adjusted to a volume of $50 \mathrm{~mL}$.

To confirm the best-chosen conditions for wine digestion standard additions for checking the accuracy of the microwave digestion and recoveries were calculated (Table 6). The digestion seemed visually completed in all of the combinations, but the spiked recoveries showed significant differences for total elements content $(p=0.005)$. 
Table 6. Accuracy of the ICP-MS determination of metals in reference materials (NIST SRM 1572) $(n=7)$

\begin{tabular}{|c|c|c|}
\hline Element & $\begin{array}{c}\text { Certified } \\
\text { Concentration } \\
(\mathrm{mg} / \mathrm{L})\end{array}$ & $\begin{array}{c}\text { Measured } \\
\text { Concentration } \\
(\mathrm{mg} / \mathrm{L})\end{array}$ \\
\hline $\mathrm{Mg}$ & $5.80 \pm 0.30$ & $5.74 \pm 0.01$ \\
\hline $\mathrm{Ca}$ & $31.10 \pm 1.10$ & $31.05 \pm 2.11$ \\
\hline $\mathrm{K}$ & $1.82 \pm 0.06$ & $1.79 \pm 0.05$ \\
\hline $\mathrm{Mn}$ & $23.00 \pm 2.00$ & $23.05 \pm 0.09$ \\
\hline $\mathrm{Fe}$ & $90.00 \pm 10.00$ & $89.08 \pm 6.78$ \\
\hline $\mathrm{Co}$ & $20.00 \pm 0.01$ & $21.45 \pm 2.33$ \\
\hline $\mathrm{Ni}$ & $600.00 \pm 300.00$ & $612.34 \pm 27.98$ \\
\hline $\mathrm{Cr}$ & $0.80 \pm 0.20$ & $0.79 \pm 3.22$ \\
\hline $\mathrm{Cu}$ & $16.50 \pm 1.00$ & $16.49 \pm 1.22$ \\
\hline $\mathrm{Pb}$ & $13.30 \pm 2.40$ & $13.30 \pm 2.56$ \\
\hline $\mathrm{Cd}$ & $36.00 \pm 0.10$ & $36.67 \pm 1.05$ \\
\hline $\mathrm{Zn}$ & $29.00 \pm 2.00$ & $29.34 \pm 0.99$ \\
\hline
\end{tabular}

\section{Instrumentation}

The elements were determined by using ICP-MS (iCAP Q Thermo scientific mode). The sample solution was pumped by a peristaltic pump from tubes arranged on autosampler (CETAC ASX-520), which was combined with a quartz cyclonic spray chamber (water-cooled $2^{\circ} \mathrm{C}$ ). The instrumental setting and operative conditions are reported in Table 7.

Table 7. ICP-MS instrumental parameters

\begin{tabular}{|c|c|}
\hline Parameter & Setting \\
\hline RF-Power & 1550 \\
\hline Reflected power & $<5$ \\
\hline Carrier gas flow (mL/min.) & 1.0 \\
\hline Plasma gas flow (L/min.) & 15 \\
\hline Auxiliary gas flow $(\mathrm{mL} / \mathrm{min})$. & 1.0 \\
\hline Spray chamber & 2 \\
\hline Spray-Chamber temperature $\left({ }^{\circ} \mathrm{C}\right)$ & 6.25 \\
\hline Lens voltage $(\mathrm{V})$ & $3-209$ \\
\hline Mass range $(\mathrm{AMU})$ & 0.7 \\
\hline Mass resolution & 3 \\
\hline Integration time points $/ \mathrm{ms}$. & 3 \\
\hline Points per peak & 3 \\
\hline Replicates & \\
\hline
\end{tabular}


The instrument was daily optimized to give maximum sensitivity for $\mathrm{M}^{+}$ions and the double ionization and oxides monitored by the means of the ratios between $\mathrm{Ba}^{2+} / \mathrm{Ba}^{+}$and $\mathrm{Ce}^{2+} / \mathrm{CeO}^{+}$, respectively, these always being less than $2 \%$.

\section{Estimation of dietary intake (EDI) and THQ}

The adult per capita consumption rate of pure alcohol in Romania is 14.4 $\mathrm{L}$ per annum. This value is from the calculation based on the Food and Agriculture Organization of the United Nations data, which includes fermented beverages and estimates of beer produced locally from sorghum, millet, and other agricultural products [36]. In this study, an adult per capita consumption rate of $14.4 \mathrm{~L}$ per annum of spirits, which is equivalent to $39 \mathrm{~mL}$ per day, and an average weight of $70 \mathrm{Kg}$ per adult was adopted. EDI is measured in $\mu \mathrm{g} / \mathrm{kg}$ b.w. [37].

$$
E D I=(F I R \times C) / B w a
$$

where EDI is estimated daily intake ( $\mu \mathrm{g}$ analysed element $/ \mathrm{kg}$ body weight/day), FIR is average daily consumption of alcohol $(\mathrm{mL} / \mathrm{kg}), \mathrm{C}$ is average concentration of the heavy metals in the samples $(\mu \mathrm{g} / \mathrm{mL})$ and Bwa is average body weight $(\mathrm{Kg})[37,16]$.

To assess the human risk from consumption of alcoholic beverages with metals, the target Hazard Quotient (THQ) was calculated as per the US EPA Region III Risk-Based Concentration Table [USEPA] (United States Environmental Protection Agency) 2011] [37]. The THQ is an estimate of the non-carcinogenic risk level due to pollutant exposure and calculated by the following equation:

$$
\mathrm{THQ}=10^{-3} \times(\text { Efr } \times \text { EDtot } \times \text { Fir } \times \mathrm{C}) /(\text { RfDo } \times \text { Bwa } \times \text { ATn })
$$

where, THQ is target hazard quotient, Efr - exposure frequency (365 days/year), EDtot - exposure duration (70 years), FIR - average daily consumption of alcohol $(\mathrm{mL} / \mathrm{kg}), \mathrm{C}$ - average concentration of the metals in samples $(\mu \mathrm{g} / \mathrm{mL})$, RfDo - oral reference dose $(\mathrm{mg} / \mathrm{kg} /$ day), Bwa - average body weight $(\mathrm{kg})$ and ATn - average exposure for non-carcinogens in year (365 days/year $\times 70$ years). THQ value below 1 indicant no adverse effect on human health. 


\section{Statistical analysis}

The statistical interpretation of the results was performed using the Duncan test, SPSS Version 24 (SPSS Inc., Chicago, IL., USA). The statistical processing of the results was primarily performed to calculate the following statistical parameters: average and standard deviation. This data was interpreted with the analysis of variance (ANOVA) and the average separation was performed with the DUNCAN test at $p \leq 0.05$.

\section{ACKNOWLEDGMENTS}

This project is funded by the Ministry of Research and Innovation through Program 1 - Development of the National Research and Development System, Subprogram 1.2 - Institutional Performance - Projects for Financing the Excellence in CDI, Contract no. 37PFE/06.11.2018. Title of the project: "Increasing the institutional performance through consolidation and development of research directions within the USAMVCN".

\section{REFERENCES}

1. J.G. Ibanez; A. Carreon-Alvarez; M. Barcena-Soto; N. Casillas; J. Food Compos. Anal., 2008, 21, 672-683.

2. A.M. Green; A.C. Clark; G.R. Scollary; Fresenius J. Anal. Chem., 1997, 358, 711-717.

3. K. Akrida-Demertzi; A.A. Koutinas; Dev. Food Sci., 1992, 29, 475-489.

4. H. Mayer, O, Marconi; S. Floridi; L. Montanari; P. Fantozzi; J. Inst. Brew., 2003, 109(4), 332-336.

5. R. Kokkinofta; P. V. Petrakis; T. Mavromoustakos; C.R. Theocharis; J. Agric. Food Chem., 2003, 6233-6239.

6. F. Salvo; L.L., Bella; G.D. Nicotina; M. Dugo; J. Agric. Food Chem., 2003, 51, 1090-1094.

7. P. Pohl; Trends Anal. Chem., 2007, 26(9), 941-949.

8. T. Adam; E. Duthie; E.J. Feldmann; J. Inst. Brew., 2002, 108(4), 459-464.

9. G. Dugo; L.L. Pera; V.L. Bella; G.D. Salvo; J. Agric. Food Chem., 2005, 52, 1829-1834.

10. M. Navarro-Alarcon; Food Addit. Contam., 2007, 24(7): 685-694.

11. A. Carreon; N. Casillas; V. Gonzalez-Alvarez; R. Prado-Ramirez; Mater. Performance, 2001, 50-52.

12. M.I. Guerrero; C. Herce-Paglia; A.G. Gonzalez; F.J. Heredia; A.M. Troncoso; A. M. Camean; Sci. Aliment, 1996, 16: 143-149.

13. C. Reilly; J. Sci. Food Agric., 1972, 23(9): 1143-1144.

14. C. Reilly; Ecol. Food Nutr., 1973, 2(1): 43-47. 
15. C.M. Mena; C. Cabrera; M.L. Lorenzo; M.C. Lopez; J. Agric. Food Chem., 1997, 45: 1812-1815.

16. C.M.A. Iwegbue; L.O. Overah; F.I. Bassey; B.S. Martincigh; J. Inst. Brew., 2013, 120: $521-528$.

17. A.M. Cameán; I. Moreno; M. López-Artíguez; M. Repetto; A.G. González; Talanta, 2001, 54: 53-59.

18. V. Ivanova-Petropulos; H. Wiltsche; T. Stafilov; M. Stafilov; H. Lankmayr; Maced. J. Chem. Chem. Eng., 2013, 32(2): 265-281.

19. S. Ražić; A. Onjia; Am. J. Enol. Viticult., 2010, 61(4): 506-511.

20. P. Kment; M. Mihaljević; M. Ettler; O. Šebek; L. Strand; L. Rohlová; Food Chem., 2005, 91(1): 157-165.

21. S.R. Gilbson; Principles of nutritional assessment, Oxford University Press, Oxford, 2005, pp. 341-352.

22. E.H. Soufleros, A.S. Mygdalia; P. Natskoulis; Food Chem., 2004, 86: 625-636.

23. C. Macca; M. Bradshaw; A. Merkoci; C. Scollary; Anal. Lett., 1997, 30(6), 12231234.

24. R.F. Nascimento; C.WB. Bezerra; S. M.B. Furuya; M.S. Schultz; L.R. Polastro; B.S. Lima Neto; D.W. Franco; J. Food Compos. Anal., 1999, 12: 17-25.

25. F.D. Bora; A. Donici; T. Rusu; A. Bunea; D. Popescu; C.I. Bunea; Not. Bot. Horti. Agrobo., 2018, 46(1): 223-239.

26. M. Iglesias; E. Besalú; E. Anticó; J. Agric. Food Chem., 2007, 55(2): 219-225.

27. C. Reilly; Ecol. Food Nutr., 1973, 2(1): 43-47.

28. F.A. Cyro; An. Farm. Quim. S. Paulo, 1976, 16(1): 61-67.

29. S. Xuebo; H. Min; Z. Li; L. Zhu; F. Zheng; M. Huang; X. Sun; H. Li; F. Chen; B. Sun; J. Food, Saf., 2018, 2: 43-49.

30. T. Hague; A. Petroczi; P.L.R. Andrews; J. Barker; D. Naughon; Chem. Central J., 2008, 4(1): 1-3.

31. D.P. Naughton; A. Petroczi; Immun. Ageing, 2008, 5(1): 3. DOI: 10.1186/17424933-5-3.

32. D.P. Naughton; A. Petroczi; Chem. Central J., 2008, 2(22). DOI: 10.1186/1752153X-2-22.

33. R.K., Sharma; M. Agrawal; J. Envrion. 2005, Biol., 26: 301-313.

34. L.C. Chien; T.C. Hung; Y.K. Choang; C.Y. Yeh; P.J. Meng; M.J. Skieh; B.C. Han; 2002, Sci. Total Environ., 285: 177-185.

35. E.I. Geana, C. Sandru, V. Stanciu, et al., Food Anal. Method, 2017, 10(1), 6373.

36. World Health Organization, Department of Mental Health and Substance Abuse, Geneva, 2004.

37. B. Song; M. Lei; T. Chen; Y.M. Zheng; Y.F. Xie; X.Y. Li; D. Gao; J. Environ. Sci., 2009, 21: 1702-1709. 